\title{
Changes in marketing strategy structure based on smartphones
}

\author{
Weidong $\mathrm{Xi}^{1, *}$ \\ ${ }^{1}$ Dalian university of science and technology, School of economics and management,116052 Dalian, Liaoning province
}

\begin{abstract}
With the spread of smartphones, customers have begun to make purchasing behaviors "anytime" and "anywhere", creating a purchasing process in an omni-channel society. Toward an omni-channel society, production consumers are transforming into production promotion consumers, and marketing continues to transform into channel interactive real marketing in order to respond to that change. Channel interactive realtime marketing, which enables self-fulfillment of customers and enterprises, has reached the realm of marketing 4.0. Channel interactive real-time marketing maximizes the effectiveness of improving marketing ROI. Channel interactive real-time marketing implements seamless inter-channel cooperation, two-way communication, etc., which makes customer response more detailed, further improving the ROI for each channel and maximizing the return on investment of marketing.
\end{abstract}

\section{Purchasing process transformation and channel strategy transformation}

With the spread of smartphones, customers have begun to purchase "anytime" and "anywhere", creating a purchasing process in an omni-channel society. Utilizing contact points "anytime" and "anywhere" based on smartphones, rather than simply linking data between real stores and online stores. Companies are required to find out how to connect the real world and the Internet, and what kind of products and services to provide to customers. The concept of sales channels has changed to singlechannel, multi-channel, cross-channel, and omni-channel due to changes in contact points with customers due to changes in customer purchasing behavior.

Until the second half of the 20th century, the point of contact between customers and businesses was a single channel for physical stores only. Focused on optimizing its performance using a single channel. In the 21 st century, the rapid development of ICT has diversified and sophisticated sales channels. In multi-channel, each channel had an independent contact point. There were multiple channels such as physical stores, online stores, and telephones, but each customer contacted each channel, there was no cooperation of services across channels, and the real and the Internet were not fused. With the further sophistication of cross-channel, each channel will be linked with information. It is the same as multi-channel in that there are multiple contact points between customers and companies, such as physical stores, online stores, and telephones. One customer can use multiple channels properly, and information and data crossing has begun between channels. With cross-channel, products purchased at online stores can be received at stores, and points can now be used in common online and at stores.

In the omni-channel era, customer and enterprise contact points are fully integrated and seamless across all channels. Customers can search for and purchase products and services "anytime" and "anywhere" without being aware of the difference in channels between physical stores and online stores. Product inventories are unified from stores, telephones, and smartphones, and customers can select the channel they want for receiving and payment. You can search for similar products online at stores, listen to the opinions of friends and acquaintances through SNS, and browse user impressions on word-ofmouth sites. You can buy it online or listen to the explanation on a videophone. Omni-channel makes it possible to effectively utilize the merits of both physical stores and online stores and realize a stress-free purchasing experience.

\section{Marketing mix model in an omni- channel society}

Marketing mix 4P is a marketing theory that emphasizes the seller's perspective of a producer-led company, and $4 \mathrm{C}$ is a marketing theory that emphasizes the buyer's perspective of a consumer-led customer (Table 1).

Table 1. 4P and 4C concepts.

\begin{tabular}{|c|c|}
\hline $4 \mathrm{P}$ & $4 \mathrm{C}$ \\
\hline Product & Customer Value \\
\hline Price & Cost \\
\hline Promotion & Communication \\
\hline Place & Convenience \\
\hline$\downarrow$ & $\downarrow$ \\
\hline Profit & Confidence \\
\hline
\end{tabular}

Production Promotion In a consumer-led omnichannel society, we will explain the marketing theory that emphasizes the customer's buyer's perspective rather than 
the marketing mix 4C theory.

Each element of the marketing mix 4P (Product, Price, Promotion, Place) and 4C (Customer Value, Cost, Communication, Convenience) derive the marketing mix model required in an omni-channel society.

In an omni-channel society, eight "Cs" have been added to the existing 4Cs (Customer Value, Cost, Communication, Convenience) and new 4Cs (Commodity, Customer Price, Customer Information, Channel) as elements of the marketing mix. (Fig. 1).

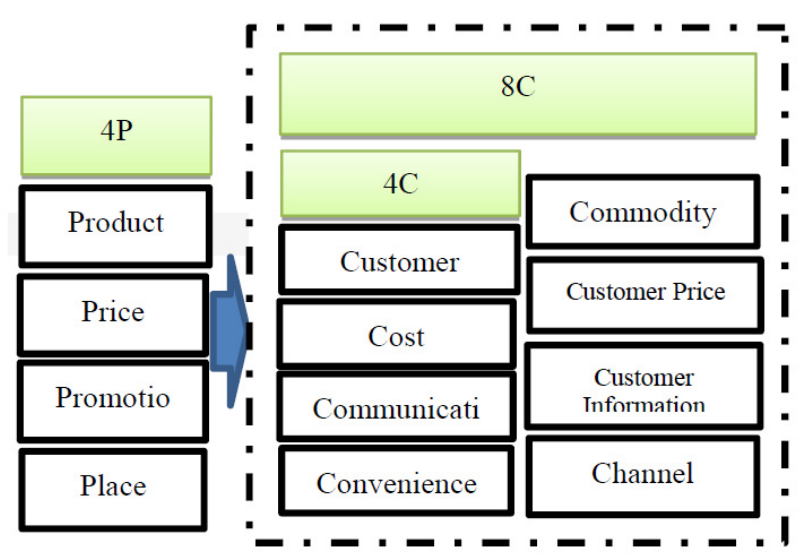

Fig. 1. 4P、 $4 \mathrm{C} 、 8 \mathrm{C}$ framework.

We define $8 \mathrm{C}$ of omni-channel as "Customer Value", "Cost", "Communication", "Convenience", "Commodity", "Customer Price", "Customer Information", and "Channel".The final goal in the marketing mix 4P is Profit, and in $4 \mathrm{C}$ it is Confidence. Even in $8 \mathrm{C}$, customers are fixed (Loyalty) by building Confidence.

\section{Marketing 4.0}

\subsection{Marketing 1.0}

The period of high economic miracle, which was said to be a shortage of goods, was an era in which goods could easily be sold.In the market where there is a shortage of goods, improving production capacity is a marketing proposition for companies. After that, corporate efforts will improve productivity and enable mass production, and when goods begin to be supplied to the market, the balance between supply and demand will be balanced. In such an environment, strengthening promotion strategies turns into a marketing proposition in order for companies to sell the products they produce in large quantities.

Eventually, as we enter the era of surplus goods, with the progress of ICT, customers will be able to easily obtain information on goods, and the demand for goods will increase. The marketing proposition shifts to providing the products that customers want. Furthermore, the idea of never providing anything that has an adverse effect in the light of social norms, even if the customer wants it, will be adopted as a marketing proposition.

Marketing 1.0 is producer-led product-centric marketing. The purpose was to keep production costs as low as possible through manufacturing technology, provide cheap and good products and services, and sell them to the mass market.

\subsection{Marketing 2.0}

Marketing 2.0 is consumer-driven, customer-oriented marketing. The leadership position has shifted from the company to the customer. In an era where customers can get what they need, customers are no longer satisfied just because the functional value of products and services is high. The functional value of products and services is now decided by customers, not by companies. It was necessary to start from customer needs, and the differentiated emotional value that grabbed the heart of the customer became important.

\subsection{Marketing 3.0}

Marketing 3.0 is value-driven marketing. Instead of the functional value of a product or service, it has become important what kind of corporate mindset and vision the product or service was created in the background. Through social contribution through CSR activities, it is more important for companies to provide not only products and services but also spiritual value and social value to their customers. Philip Kotler today advocates the need for a new marketing 4.0 concept.

\subsection{Marketing 4.0}

Marketing 4.0 is self-actualization-led marketing. As a result of purchasing goods and services and using them, the focus is on how close the customer can be to his or her own self, his true self, his ideal self, or his new self. In terms of drinks, Marketing 1.0 sells cheap and delicious drinks. The company sells the cheap and delicious features themselves. Marketing 2.0 offers added value other than the value of the drink itself, which is free to carry and can be drunk anytime, anywhere by selling the drink in a PET bottle container. In Marketing 3.0, by making it a recyclable PET bottle, it will be a drink in an environmentally friendly container, and it will be ecofriendly. This is the so-called corporate social contribution.Marketing 4.0 enables customers to realize themselves by making health-conscious drinks that have a dieting effect such as fat burning. By clarifying the mindset and vision of the company, thinking from the potential needs of the customer, and being aware that the customer can achieve self-actualization, it is possible to create the value of truly powerful products and services. The meaning of self-actualization in Marketing 4.0 is considered to be the same as satisfying the selfactualization desire of psychologist Abraham Maslow's five-step theory. At this point, as society becomes more prosperous, the desire to belong to a group that values oneself, such as family, that is, the desire for affiliation and love, is being satisfied. SNS has a great influence on customers' desire for self-actualization. I have come to want to express myself through social media and be recognized as a valuable being, and I am trying to reach the desire for self-actualization beyond that desire for dignity. It can foresee the concept of "super-ego" such as "self-creation" that recreates itself and "co-creation" that tries to recreate itself from the community. 


\section{Genealogy of marketing strategy transformation}

In the 1970s, when the value of the product itself was sold, one-way mass marketing such as TV commercials was the mainstream, creating contact points with customers through a single channel only at the store. In the marketing mix, 4P was advocated from the perspective of the company. In the $1980 \mathrm{~s}$, the purchasing process began to shift to consumer-led, and the concept of replacing his $4 \mathrm{P}$ with his 4C from the customer's point of view was advocated. In the 1990s, the channel transformation due to the introduction of IT evolved from single channel to multi-channel and cross-channel, and with the support of ICT, it progressed to omni-channel. In the meantime, marketing will transform into segment marketing with human-based targeting, targeted marketing with one-toone marketing, and event-based marketing that combines people, things, and things. In target marketing, there is a transition from product-led marketing to things-driven marketing. Toward an omni-channel society, Prosumer has changed to Promosumer, and in order to respond to that change, marketing continues to transform into channel interactive real marketing. Channel interactive real-time marketing, which enables the self-fulfillment of customers and businesses, has reached the realm of marketing 4.0 (Fig. 2).

\begin{tabular}{|c|c|c|c|c|c|c|}
\hline \multirow{3}{*}{$\begin{array}{c}\text { Ma } \\
\text { rket } \\
\text { ing }\end{array}$} & \multirow{2}{*}{$\begin{array}{l}\text { Mass } \\
\text { mark } \\
\text { eting }\end{array}$} & & \multicolumn{2}{|c|}{ target marketing } & Event & \multirow{2}{*}{$\begin{array}{l}\text { channel } \\
\text { Interacti } \\
\text { ve Real- } \\
\text { time } \\
\text { marketin } \\
\text { g }\end{array}$} \\
\hline & & $\begin{array}{c}\text { People } \\
\text { target }\end{array}$ & $\begin{array}{l}\text { mono } \\
\text { target }\end{array}$ & $\begin{array}{c}\text { Thing } \\
s \\
\text { target }\end{array}$ & $\begin{array}{c}\text { People、 } \\
\text { Things } \\
\text { target }\end{array}$ & \\
\hline & \multicolumn{2}{|c|}{$\begin{array}{l}\text { Marketing 1.0 } \\
\text { Product- } \\
\text { oriented }\end{array}$} & \multicolumn{2}{|c|}{$\begin{array}{c}\text { Marketing } 2.0 \\
\text { Customer } \\
\text { ambition }\end{array}$} & $\begin{array}{c}\text { Marketing } \\
3.0 \\
\text { Socially } \\
\text { creative }\end{array}$ & $\begin{array}{c}\text { Market } \\
\text { ing } 4.0 \\
\text { Self- } \\
\text { experie } \\
\text { nce }\end{array}$ \\
\hline
\end{tabular}

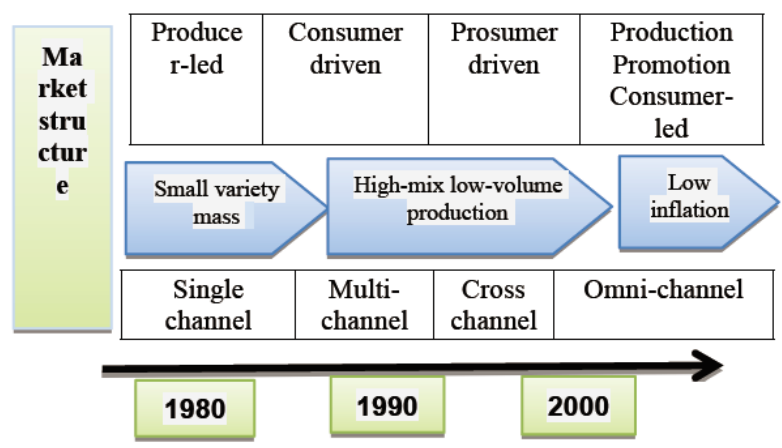

Fig. 2. Turning points for marketing strategy transformation.

\section{Marketing strategy innovation}

In mass marketing, companies place importance on expanding market share through one-way communication of product and service functions and brand messages through media such as television. It is after the fact that the message is sent that the reaction of each customer is verified to see if the message to be sent reaches the individual customer. Therefore, it takes a considerable amount of time for accurate grasping.Aiming for mass production and mass sales, we will secure a sales floor through the network and gain market share through a single channel of real stores. Direct marketing emphasizes two-way communication with individual customers through customer-oriented and IT-based multi-channel real stores and online stores. In addition to the basic attributes of individual customers, opinions on the functions of products and services are analyzed in a database, and then the potential needs of customers are read and understood. The real and the net have not been fused yet, and the net will become the center.

Channel interactive real-time marketing emphasizes continuous and repetitive dialogue with individual customers through omni-channel integration of real stores and online stores. In addition to the basic attributes and purchase history of individual customers, we will respond to individual customer needs in real time by making full use of call center call recordings, action records by surveillance cameras in real stores, and all kinds of databases, so-called big data. Big data is essential for channel interactive real-time marketing. Due to the increase in users of blogs, video sites, and SNS, not only characters but also digital data such as voice are stored in servers on the Internet and stored in databases. Big data allows you to get a closer look at what your customers are and share customer information across all channels to stay ahead of the potential needs of your customers. Marketing has evolved with the keywords of customer orientation and ICT. And it is still evolving (Table 2).

Table2. Evolution of marketing strategy

\begin{tabular}{|c|c|c|c|}
\hline strategy & $\begin{array}{c}\text { Mass } \\
\text { marketing }\end{array}$ & $\begin{array}{c}\text { Direct } \\
\text { marketing }\end{array}$ & $\begin{array}{c}\text { Channel } \\
\text { Interactive } \\
\text { Real-Time } \\
\text { Marketing }\end{array}$ \\
\hline $\begin{array}{c}\text { point of } \\
\text { view }\end{array}$ & $\begin{array}{c}\text { Producer- } \\
\text { led }\end{array}$ & $\begin{array}{c}\text { Consumer } \\
\text { driven }\end{array}$ & $\begin{array}{c}\text { Prosumer } \\
\text { driven }\end{array}$ \\
\hline direction & $\begin{array}{c}\text { Small } \\
\text { variety } \\
\text { and large } \\
\text { amount }\end{array}$ & $\begin{array}{l}\text { More varieties } \\
\text { and less }\end{array}$ & $\begin{array}{c}\text { Very large } \\
\text { variety and } \\
\text { small amount }\end{array}$ \\
\hline $\begin{array}{l}\text { Commun } \\
\text { ication }\end{array}$ & $\begin{array}{c}\text { One } \\
\text { direction }\end{array}$ & Bidirectional & $\begin{array}{l}\text { Continuous } \\
\text { repetitive } \\
\text { dialogue }\end{array}$ \\
\hline Emphasis & $\begin{array}{l}\text { Share } \\
\text { (short } \\
\text { term) }\end{array}$ & $\begin{array}{l}\text { Efficiency, } \\
\text { effect (medium } \\
\text { term) }\end{array}$ & $\begin{array}{l}\text { LTV (long } \\
\text { term) }\end{array}$ \\
\hline $\begin{array}{l}\text { distributi } \\
\text { on }\end{array}$ & Real & $\begin{array}{c}\text { Real / net } \\
\text { center }\end{array}$ & $\begin{array}{l}\text { Real / net } \\
\text { fusion }\end{array}$ \\
\hline Channel & $\begin{array}{c}\text { Single } \\
\text { channel }\end{array}$ & $\begin{array}{l}\text { Multi-channel } \\
\text { Cross channel }\end{array}$ & Omni-channel \\
\hline IT & $\begin{array}{l}\text { Analog } \\
\text { offline }\end{array}$ & $\begin{array}{c}\text { Digital } \\
\text { Online center }\end{array}$ & $\begin{array}{l}\text { Digital } \\
\text { Offline / } \\
\text { online }\end{array}$ \\
\hline
\end{tabular}

Channel interactive real-time marketing can shorten the PDCA cycle of measures and turn them faster. In mass marketing, it takes time from planning and implementation of measures to verification. From verification to the next action, it will take a considerable amount of time due to the limited channels and analogcentric offline. On the other hand, omni-channel interactive real-time marketing is digital and one-to-one, so the next action can be performed using all channels, so 
it is possible to quickly proceed from verification to the next action.Therefore, it is possible to implement proposals that are one step ahead of customer needs at the optimal timing and on the optimal channel, and to realize cross-sales and up-sales in a short time. Since PDCA can be rotated in a short time, corrections can be made in real time, and the results can be immediately linked to the next results, it is possible to quickly create a fan base of customers.

\section{Effectiveness of Omni-Channel Interactive Real-Time Marketing Strategy}

Channel interactive real-time marketing maximizes the effectiveness of improving marketing ROI. Targeting is the most important factor in maximizing the return on investment of marketing conducted. Channels with high ROI performance are targeted implementations with low costs.Therefore, direct methods such as email and affiliates have high marketing ROI. On the other hand, TV and newspaper advertisements, which are conventional marketing methods, have a low ROI because they are expensive and difficult to achieve results. Therefore, direct marketing has a higher ROI than mass marketing and segment marketing. In addition, event-based marketing, which is a method that captures changes in customer behavior and triggers marketing implementation, further enhances ROI. Companies are the triggers for marketing, but there are various timings when customer needs for specific products and services emerge. Effective and efficient results can be expected if the timing of the trigger of marketing implementation of the company and the expression of customer needs match. Event-based marketing can improve marketing ROI because it triggers marketing implementation at the timing when customer needs for specific products and services are high.

Finally, channel interactive real-time marketing implements seamless channel-to-channel cooperation, real-time information transmission, two-way communication, etc., in addition to direct marketing and event-based marketing methods. As customer response becomes more detailed, ROI for each channel will be further improved, and the return on investment of marketing will be maximized. From the effectiveness of the marketing implemented, it can be understood that the company is shifting from the mass marketing strategy to the direct marketing strategy, and the channel interactive real-time marketing strategy can pursue further effectiveness.

\section{Conclusion}

With the development of ICT technology and the spread of smartphones and SNS, opportunities for communication with corporate customers have increased dramatically. Advances in ICT technologies such as NFC, Bluetooth, and NFRC will not only change the way traditional marketing works, but also accelerate the speed of marketing evolution. The business format of only physical stores is required to change, and it is necessary to break away from the single channel of only physical stores. There is a need for a paradigm shift in the business model to omni-channel, and the era of being eliminated without implementing the omni-channel strategy has arrived. Omni-channel must be realized by seamlessly sharing customer information, inventory management, etc. across all channels and providing the products, services, and optimal purchasing experience that customers want. In the omni-channel strategy era, companies must work on omni-channel marketing company-wide.

\section{Reference}

1. Wang Mimi , "Research on Marketing Model Integration and Innovation Mechanism from the Channel Perspective ",Business Economic Research,vol. 20, pp. 67-70, Oct2020.

2. Kong Yanfen, "Innovation of retail marketing model based on omni-channel marketing theory ",Modern marketing, vol. 12, pp.74-75, Feb2020.

3. Zhou Yawen, "On the Innovation of Commercial Models of Retail Enterprises under the Omni-channel Marketing Model",Marketing, vol. 33, pp. 139, Oct 2019.

4. Dong Changliang, "New retail business value appreciation and innovation strategies under the omni-channel marketing model",Coastal Enterprise and Technology ,vol. 8, pp. 11-15, Aug. t2020. 